\title{
PENGUATAN KARAKTER MELALUI PENDIDIKAN ISLAM DI TK MAWADDAH KOTA BANJARMASIN
}

\author{
Abd. Muin M \\ Peneliti Puslitbang Pendidikan Agama dan Keagamaan \\ Jl. MH Thamrin No. 06 Jakarta Pusat \\ abd.muinfikri@yahoo.com
}

\section{Abstrak}

Penelitian ini menggunakan metode kualitatif, bertujuan untuk mengungkapkan motede pembelajaran dan strategi penguatan karakter anak didik melalui pendidikan Islam. Dari penelitian ini diungkapkan, bahwa sejak berdiri taman kanak-kanak ini konsisten menginternalisasikan nilai-nilai pendidikan Islam kepada anak didiksebagaipondasipenguatan karakter. Dengan metode pembelajaran Beyond Centers and Circle Time. Metode ini sangat relevan kebutuhan anak didik, yaitu dunia bermain, sehingga memperlancar proses pembelajaran. Sedangkan strategi penguatan karakter dilakukan melalui proses panjang dan berkesinambungan dalam menginternalisasikan nilai-nilai pendidikan Islam melalui pengenalan, pembiasaan dan keteladanan yang didukung kemampuan orangtua mendidik anak yang diperoleh melalui kegiatan parenting class.

Keywords: Karakter, Pendidikan Islam, Anak Usia Dini

\section{Abstract}

This study aims to reveal: 1) an overview of Mawaddah kindergarten, 2) the learning method of Mawaddah kindergarten and 3) the developing strategies to strengthen the character of the students through Islamic education. This study uses qualitative methods; the data was collected through interviews, observation and documentation. The results show that since Mawaddah kindergarten was established, it has been consistent in teaching the values of Islamic education in the belief that these values will become a solid foundation to strengthen students' character. The "Beyond Centers and Circle Time" method, which is known as sentra method, appears to be very relevant to the needs of children-fun. The strategy of strengthening character does not stop there. It continues in the family with supports for parents' ability to educate children through parenting classes. Strengthening character cannot be accomplished in an instant; it can only be accomplished through a long and continuous process using the values of Islamic education through introduction, habituation and positive examples.

Keywords: Character, Islamic Education, Early Childhood

\section{PENDAHULUAN}

\section{Latar Belakang Masalah}

Rencana Pembangunan Jangka Panjang Nasional Tahun 2005-2025 pemerintah menempatkan pendidikan karakter sebagai misi pertama dari delapan misi guna mewujudkan visi pembangunan nasional. Juga, dalam perbagai kesempatan, Presiden RI mengemukakan pentingnya membangun watak (character building), untuk membangun 
manusia berakhlak, berbudi pekerti dan berperilaku baik. ${ }^{1}$

Merespon hal tersebut, salah satu strategi yang ditempuh/ke arah itu adalah melalui pendidikan. Menurut Dewantara pendidikan tidak hanya bertujuan membentuk anak didik menjadi pandai, pintar, berpengetahuan dan cerdas. Tapi, juga berorientasi kepada pembentukan manusia yang berbudi pekerti, berkepribadian dan bersusila yang luhur. ${ }^{2}$ Karena itu, satuan pendidikan merupakan komponen penting dalam pembangunan karakter yang berjalan secara sistematik dan integratif dengan berbagai komponen lainnya. William Bennett dalam Wibowo mengemukakan, sekolah memiliki peran yang sangat penting dalam pendidikan karakter anak didik, sebab apa yang terekam dalam memori anak didik di sekolah berpengaruh sangat besar bagi keperibadian mereka ketika dewasa kelak. ${ }^{3}$

Pendidikan yang paling mendasar dan menempati posisi sebagai golden age, khususnya dalam pengenalan dan pembiasaan nilai-nilai karakter adalah anak usia dini. Dalam hal ini, menurut Soerdarsono persemaian karakter yang paling baik adalah bila dilakukan sejak anak usia dini, bahkan sejak bayi masih berada dalam kandungan. ${ }^{4}$

Undang-Undang RI Nomor 20 Tahun 2003 Tentang Sistem Pendidikan Nasional Pasal 28 ayat (3) Pendidikan anak usia dini pada jalur pendidikan formal berbentuk taman kanakkanak (TK) dan raudhatul athfal (RA) atau bentuk lain yang sederajat. Senada dengan ini, Peraturan Pemerintah RI Nomor 27 Tahun 1990 Tentang Pendidikan Prasekolah Pasal 9 ayat

${ }^{1}$ Pemerintah RI. 2010. Desain Induk Pembangunan Karakter Bangsa Tahun 2010-2025. Jakarta: Pemerintah RI, h. i.

${ }^{2}$ Ki Hadjar Dewantara. tt. Karya Ki Hadjar Dewantara Bagian Pertama Pendidikan. Yogyakarta: Mejelis Luhur Persatuan Taman Siswa, h. 91.

${ }^{3}$ Agus Wibowo. 2012. Pendidikan Karakter: Strategi Membangun Karakter Bangsa Berperadaban. Yogyakarta: Pustaka Pelajar, h. 54.

${ }^{4}$ Soemarno Soedarsono. 2009. Karakter Mengantar Bangsa Dari Gelap Menuju Terang. Jakarta: Elex Media Kompurindo, h. 182.
(1) antara lain, disebutkan bahwa pendidikan agama merupakan program kegiatan belajar pendidikan di taman kanak-kanak. Karena itu, perkembangan taman kanak-kanak di Kota Banjarmasin yang didukung oleh budaya religius merupakan potensi untuk penguatan karakter melalui pendidikan agama, sebab setiap taman kanak-kanak dituntut membelajarkan pendidikan agama.

Taman kanak-kanak sebagai satuan pendidikan formal sangat strategis sebagai wahana penguatan karakter melalui pendidikan agama yang dapat dilakukan dengan menggunakan: (1) pendekatan terintegrasi dalam semua mata pelajaran, (b) pengembangan budaya satuan pendidikan, (c) pelaksanaan kegiatan kokurikuler dan ekstrakurikuler, dan (d) pembiasaan perlaku dalam kehidupan di lingkungan satuan pendidikan. Ini dilakukan mulai dari pendidikan usia dini .... ${ }^{5}$

Penguatan karakter anak didik taman kanak-kanak sangat relevan dengan proses tingkat perkembangan psikologi anak. Untuk itu, penguatan karakter anak didik melalui pendidikan agama Islam peneliti menduga telah dilaksanakan. Namun, keadaan tersebut dilanda berbagai dampak negatif, antara lain: terjadi pergesaran nilai-nilai moral dan etika dalam berbagai aspek kehidupan masyarakat, seperti; memudarnya penghargaan terhadap: nilai-nilai solidiritas sosial, musyawarah mufakat, kekeluargaan, sopan-santum, kejujuran, rasa malu dan lainnya. Selain itu, perlaku korupsi, kekerasan, pelecehan seksual dan kejahatan lainnya sering terjadi bagaikan senetron berepisode yang tiada akhir.

Pergeseran nilai-nilaI tersebut, diduga karena karakter mereka kurang kuat untuk memfilter dan membentengi diri dari berbagai dampak negatif modernisasi dan globalisasi, maka untuk mengatasi pergeseran nilai-nilai tersebutadalah penguatan karakter anak sedini mungkin melalui pendidikan Islam di taman kanak-kanak, sehingga anak sebagai generasi penerus bangsa kelak setelah dewasa memiliki

\footnotetext{
${ }^{5}$ Pemerintah RI. 2010. Op. Cit., h. 5.
} 
karakter yang handal. Untuk itu, penguatan karakter anak didik melalui pendidikan Islam di taman kanak-kanak sangat penting dan strategis untuk diteliti secara komprehensif.

Dengan demikian, fokus dan rumusan permasalahan penelitian ini adalah bagaimana gambaran umum TK Mawaddah, motode pembelajaran dan bagaimana strategi yang dikembangkan sebagai upaya penguatan karakter anak didik melalui pendidikan Islam. Untuk itu, penelitian ini bertujuan untuk mengungkapkan gambaran umum TK Mawaddah, motede pembelajaran dan strategi yang dikembangkan sebagai penguatan karakter anak didik melalui pendidikan Islam.

\section{KERANGKA KONSEPTUAL}

\section{Penguatan Karakter}

Berbagai pendapat tentang karakter, antara lain; menurut soedarsono karakter merupakan nilai-nilai yang terpatri dalam diri seseorang melalui pendidikan, pengalaman, percobaan, pengorbanan dan pengaruh lingkungan, dipadukan dengan nilai-nilai dari dalam diri sehingga menjadi nilai intristik yang mewujud dalam sistem daya juang melandasi pemikiran, sikap dan perilaku. ${ }^{6}$ Pendapat ini senada dengan Thomas Lickona dalam Wibowo, karakter merupakan sifat alami seseorang dalam merespons situasi secara bermoral. Sifat alami itu dimanifestasikan dalam tindakan nyata menjadi tingkah laku yang baik, jujur, bertanggung jawab, menghormati orang lain dan karakter mulia lainnya.

Di samping itu, Muhammad mengemukakan, bahwa pada dasarnya tidak membedakan antara pendidikan moral dengan karakter, sebab essensinya berada dalam wilayah etika. Karena semua keyakinan atau agama memiliki nilai moral atau sering disebut adab/etika/akhlak mulia. ${ }^{8}$ Juga karakter

${ }^{6}$ Soemarno Soedarsono. 2009. Op. Cit., h. 93.

${ }^{7}$ Agus Wibowo .2012. Op. Cit., h. 32 .

${ }^{8}$ Muhammad AR. 2003. Pendidikan di Alaf Baru: Rekonstruksi Atas Moralitas Pendidikan. Yogyakarta: Prismashophie Press. h. 74. dapat diartikan sebagai nilai-nilai yang unikbaik (tahu nilai kebaikan, mau berbuat baik, dan nyata berkehidupan baik) yang terpatri dalam diri dan terejawantahkan dalam perilaku. Karakter secara koheren memancar dari hasil olah pikir, olah hati, olah rasa, serta olah raga seseorang atau sekelompok orang. Karakter merupakan ciri khas seseorang atau sekelompok orang yang mengandung nilai, kemampuan, kapasitas moral, dan ketegaran dalam menghadapi kesulitan dan tantangan. ${ }^{9}$

Pendapat di atas, dapat disimpulkan bahwa yang dimaksud penguatan karakter dalam penelitian ini adalah penguatan etika, moral, kepribadian, watak, tabiat, akhlak yang dimiliki anak didik sejak lahir terpatri melalui internalisasi nilai-nilai ajaran Islam yang secara sadar diyakini dan dimanfaatkan sebagai landasaan dalam berpikir, bersikap dan berperilaku sesuai norma-norma agama, tata krama, budaya, hukum dan adat istiadat.

\section{Pendidikan Islam}

Eksistensi pendidikan Islam pada penguatan karakter anak didik dan sekaligus karakter bangsa memiliki posisi yang kuat, baik dilihat dari sudut historis, sosiologis maupun yuridis. Dalam hal ini, menurut Muhaimin pendidikan Islam adalah upaya menanamkan agama Islam atau ajaran Islam dan nilai-nilainya, agar menjadi way of life (pandangan dan sikap hidup) seseorang. Dalam pengertian ini pendidikan Islam dapat berwujud: (1) segenap kegiatan yang dilakukan seseorang atau suatu lembaga untuk membantu seorang atau sekelompok peserta didik dalam menanamkan dan/atau menumbuh kembangkan ajaran Islam dan nilainilainya; (2) segenap fenomena atau peristiwa perjumpaan antara dua orang atau lebih yang dampaknya adalah tertanamnya dan/atau tumbuh kembangnya ajaran Islam dan nilainilainya pada salah satu atau beberapa pihak. ${ }^{10}$

\footnotetext{
${ }^{9}$ Pemerintah RI. 2010. Op. Cit., h. 7.

${ }^{10}$ Muhaimin, et. al. 2002. Paradigma Pendidikan Islam. Bandung: Remaja Rosdakarya, h. 30.
} 
Begitupun, Shaleh mengemukakan bahwa pendidikan Islam dalam arti sempit adalah upaya melalui berbagai kegiatan pembelajaran agar ajaran Islam dapat dijadikan pedoman bagi kehidupannya sebagai bekal untuk menjadi hamba Allah yang mengabdi dan beribadah kepada-Nya. Sedangkan dalam arti luas adalah usaha sadar untuk mengarahkan pertumbuhan dan perkembangan anak dengan segala potensi yang dianugerahkan Allah kepadanya agar mengemban amanah dan tanggung jawab sebagai khalifah di bumi dalam pengabdiannya kepada Allah. Dalam hal ini, gambaran manusia yang diharapkan melalui proses pendidikan Islam adalah seorang muslim yang beriman dan bertakwa kepada Allah, berakhlak mulia, beramal kebaikan (amal shaleh), menjalankan perintah Allah dengan menjauhi laranganNya, menguasai ilmu pengetahuan (dunia dan akhirat), keterampilan agar dapat memikul amanah dan tangggung jawab yang dibebankan kepadanya sesuai dengan kemampuannya masing-masing. ${ }^{11}$

Di samping itu, Langgulung mengemukakan pendidikan Islam sebagai proses untuk menyiapkan generasi muda dalam mengisi perannya, mentransfer pengetahuan dan nilai-nilai ajaran Islam sesuai dengan peran dan fungsi manusia untuk beramal di dunia dan akhirat. ${ }^{12}$ Sejalan dengan pendapat ini, Arifin mengemukakan, bahwa pendidikan Islam merupakan usaha orang dewasa yang bertakwa secara sadar untuk mengarahkan dan membimbing perkembangan fithrah (kemampuan dasar) anak didik melalui nilainilai ajaran Islam ke arah titik maksimal pertumbuhan dan perkembangan. ${ }^{13}$

Pendapat di atas, berarti pendidikan Islam harus ditempatkan dalam konteks sosial kultur bangsa Indonesia, sehingga seirama pendidikan

${ }^{11}$ Abd. Rachman Shaleh. 2009. Mereka Berbicara Pendidikan Islam Sebuah Bunga Rampai (Peduli Masalah Pendidikan Islam: Revitalisasi dan Prospek Pendidikan Islam Bagi Perkembangan Anak Bangsa). Jakarta: Rajagrafindo Persada, h. 170.

${ }^{12}$ Hasan Langgulung. 1987. Asas-Asas Pendidikan Islam. Jakarta: Pustaka Al Husna, h. 27.

${ }^{13}$ Muzayin Arifin. 1981. Kapita Selekta Pendidikan. Semarang: Toha Putra, h. 38. nasional. Selain itu, menurut Pranowo pendidikan adalah proses pembentukan karakter manusia yang tidak pernah berhenti. Karena itu, pendidikan merupakan sebuah proses budaya untuk membentuk karakter guna meningkatkan harkat dan martabat manusia yang berlangsung sepanjang hayat. ${ }^{14}$

Berdasarkan uraian di atas, dapat disimpulkan bahwa yang dimaksud pendidikan Islam dalam penelitian ini adalah pendidikan yang konsep dasarnya dapat dipahami, dianalisis dan dikembangkan berdasarkan nilai-nilai ajaran Islam yang bersumber dari al Qur'an dan hadis. Dalam hal ini, pendidikan Islam tidak hanya melalui pembelajaran, di mana guru sebagai subyek pendidikan yang memiliki otoritas penuh terhadap proses pembelajaran. Tapi, penekanan pendidikan Islam terletak pada aspek pembimbingan, pembiasaan, internalisasi nilai dan keteladanan. Karena itu, pendidik (guru) lebih berperan sebagai fasilitator, inovator, motivator, mediator dan dinamisator dalam membimbing, membiasakan dan menjadi teladan yang hasanah untuk menggali dan menumbuh kembangkan penguatan karakter anak didik.

\section{METODOLOGI PENELITIAN}

Di Kota Banjarmasin terdapat 286 taman kanak-kanak, sebagian besar berstatus swasta, $285(99,60 \%)$ dan hanya sebagian kecil, 1 $(0,40 \%)$ bestatus negeri, yaitu TK Pembina. Dari 286 taman kanak-kanak ini tersebar pada lima kecamatan: Kec. Banjarmasin Utara $53(18,53 \%)$, Kec. Banjarmasin Selatan 60 (20,98\%), Kec. Banjarmasin Tengah 68 (23,78\%), Kec. Banjarmasin Barat $51 \quad(17,83 \%)$ dan Kec. Banjarmasin Timur $54(18,88 \%)$ taman kanak-kanak. ${ }^{15}$ Data ini menunjukkan, bahwa

${ }^{14}$ M. Bambang Pranowo. 2009. Mereka Berbicara Pendidikan Islam Sebuah Bunga Rampai (Masa Depan Pendidikan Islam), Jakarta: Rajagrafindo Persada, h. 25.

${ }^{15}$ Sumber: Dokumen Direktorat Pembinaan Anak Usia Dini Dinas Pendidikan Kota Banjarmasin. 2011, yang telah diolah oleh peneliti. 
taman kanak-kanak terbanyak berada di Kec. Banjarmasin tempat TK Mawaddah.

Berdasarkan data di atas, juga diperkuat observasi terhadap sejumlah taman kanakkanak dan wawancara dengan Kabid PAUD dan PNFI Dinas Pendidikan Kota Banjarmasin Djumino (55 tahun), ${ }^{16}$ disimpulkan bahwa penelitian ini tepat dilaksanakan di TK Mawaddah Kec. Banjarmasin Tengah dengan alasan, antara lain; di Kec. Banjarmasin Tengah tempat TK Mawaddah paling banyak taman kanak-kanak dibanding kecamatan lainnya. Namun, TK Mawaddah memiliki anak didik terbanyak (133 orang) dibanding taman kanakkanak lainnya, termasuk TK Aisyiah II berdiri 1953 yang berdekatan TK Mawaddah. Dalam hal ini, TK Mawaddah berada di kecamatan yang terbanyak taman kanak-kanaknya dan memiliki anak didik lebih banyak, berarti TK Mawaddah memiliki berbagai keunggulan, sehingga dapat menarik animo dan motivasi masyarakat memasukkan anaknya ke taman kanak-kanak ini.

Penelitian ini menggunakan metode kualitatif dengan alasan, antara lain; penelitian ini bersifat fenomenologis. Menurut Glaser penelitian kualitatif dilakukan karena sifat dan masalah penelitian itu sendiri menuntut untuk menggunakan metode kualitatif. Selain itu, penelitian bertujuan untuk mengungkapkan apa yang tersembunyi di balik fenomena yang sulit untuk diungkapkan dengan metode penelitian kuantitatif. ${ }^{17}$ Sejalan pendapat ini, Alwasilah mengemukakan: (a) metode kualitatif lebih memungkinkan peneliti mengidentifikasi berbagai realitas di lapangan, sehingga memungkinkan terjadi interaksi secara intens antara peneliti dengan informan yang lebih eksplisit dan mudah dilakukan. (b) tujuan penelitian ini lebih diwarnai oleh adanya interaksi di antara realitas. Karena itu, untuk memaknai kegiatan interaktif ini peneliti seyogiayanya berinteraksi secara langsung dengan para informan baik melalui wawancara

\footnotetext{
${ }^{16}$ Observasi dan wawancara dilakukan 25 Mei 2012.

${ }^{17}$ Barney Glaser \& Anselm L. Strauss. 1980. The Discovery of Grounded Theory. New York: Aldine Publishing Company, h. 72.
}

maupun observasi dalam latar alamiah, sehingga dapat memperoleh pemahaman emik (menurut pendapat informan, bukan pendapat peneliti). ${ }^{18}$

Teknik pengumpulan data dilakukan melalui observasi, wawancara dan studi dokumentasi. Dalam penelitian kualitatif, peneliti sebagai instrumen utama, meskipun peneliti menggunakan pedoman observasi dan wawancara. Hal ini dilakukan, agar peneliti bisa berempati, berinteraksi secara aktif dan dapat memahami perspektif informan. Sedangkan informan penelitian ini, terdiri dari: kepala, wakil kepala dan pendidik TK Mawaddah. Informan ini dipandang oleh peneliti banyak mengetahui (informan kunci) terhadap masalah penelitian.

Untuk menetapkan keabsahan data, peneliti menggunakan kriteria: derajat kepercayaan (credibility), keteralihan (transferability), kebergantungan (dependability) dan kepastian (confirmability). ${ }^{19}$ Sedangkan teknik pemeriksaan keabsahan data peneliti melakukannya melalui: 1) Ketekunan observasi, menemukan ciri-ciri dan unsurunsur dalam sistuasi yang sangat relevan dengan persoalan atau issu yang sedang diteliti, kemudian peneliti memusatkan diri pada halhal tersebut secara rinci. ${ }^{20}$ 2) Triangulasi: (a) triangulasi sumber, peneliti membandingkan data/informasi hasil observasi dengan hasil wawancara, membandingkan apa yang dikatakan orang di depan umum dengan apa yang dikatakannya secara pribadi dan membandingkan hasil wawancara dengan isi dokumen yang berkaitan, dan (b) triangulasi metode, peneliti melakukan pengecekan derajat kepercayaan beberapa sumber data/ informasi dengan metode yang sama. ${ }^{21}$

Pada dasarnya, analisis data kualitatif dilakukan ketika peneliti masih dalam

${ }^{18} \mathrm{~A}$. Chaedar Alwasilah. 2003. Pokoknya Kualitatif. Jakarta: Dunia Pustaka Jaya, h. 103-105.

${ }^{19}$ Lexy J. Moleong. 2004. Metodologi Penelitian Kualitatif. Bandung: Remaja Rosdakarya, h. 324.

${ }^{20}$ Lexy J. Moleong. 2004. Ibid., h. 329.

${ }^{21}$ Michael Quinn Patton. 1987. Qualitative Evaluation Methods. Beverly Hills: Sage Publication, h. 329 - 331. 
proses pengumpulan data lapangan. Dalam hal ini, teknik analisis data yang digunakan oleh peneliti adalah teknik analisis data menurut Miles dan Huberman, terdiri dari: (1) reduksi data, (2) penyajian data, (3) menarik kesimpulan/verifikasi.

Reduksi data, ini merupakan proses dalam pemilihan, pemusatan perhatian, pengabstraksian dan pentransformasikan data kasar yang diperoleh baik melalui obeservasi, wawancara maupun dokumen-dokumen terkait. Proses ini dilakukan peneliti selama penelitian berlangsung. Awalnya, melalui permasalahan dan kerangka konseptual. Selama penelitian berlangsung, peneliti membuat ringkasan, coding, mencatat berbagai dokumen terkait dan sebagainya. Dalam hal ini, reduksi data merupakan bagian yang tidak terpisahkan dari analisis, ini berfungsi untuk lebih menajamkan, mengidentifikasi, mengarahkan dan mengorganisasikan, sehingga penafsiran data mudah dilakukan. Karena itu, dalam mereduksi data, peneliti berupaya mencari dan menemukan data yang benar-benar valid. Jika, terdapat data yang meragukan kebenarannya, maka peneliti melakukan triangulasi.

Penyajian data, merupakan data/ informasi yang terkumpul dan tersusun, sehingga memungkinkan peneliti mengambil suatu kesimpulan dalam bentuk, seperti naratif. Ini bertujuan untuk lebih memudahkan peneliti membaca dan mengambil kesimpulan. Dalam hal ini, penyajian data, juga merupakan bagian yang tidak terpisahkan dari analisis, bahkan meliputi pula reduksi data. Proses penyajian data, peneliti mengidentifkasi dan mengkategorisasi data kepada beberapa kategori. Setiap kategori data dapat menunjukkan tipologi data berdasarkan rumusan masalah penelitian. Karena itu, dalam proses ini peneliti lebih fokus untuk mengklasifikasi dan mengidentifikasi data/ informasi sesuai dengan tema-tema inti berdasarkan kebutuhan.

Menarik kesimpulan/verifikasi, merupakan bagian dari konfigurasi yang utuh.
Dalam kegiatan ini, berbagai kesimpulan telah ditetapkan dalam penelitian yang sedang berlangsung dapat diverifikasi, sehingga kesimpulan tersebut dapat teruji kebenarannya, ini dilakukan oleh peneliti untuk menjaga tingkat validitas. Selain itu, peneliti membuat rumusan proposisi dengan tetap mengutamakan prinsip logika, sehingga dapat dijadikan sebagai temuan penelitian. ${ }^{22}$

\section{HASIL DAN PEMBAHASAN}

\section{Gambaran Umum TK Mawaddah}

Berdasarkan wawancara, ${ }^{23}$ dapat disimpulkan bahwa berbagai faktor yang mendasari masyarakat mendirikan dan menyelenggarakan TK Mawaddah ini, antara lain; masyarakat menyadari bahwa pada hakikatnya anak usia taman kanak-kanak adalah masa usia yang sangat menentukan bagi pertumbuhan dan perkembangan anak, sebab pada usia ini adalah masa keemasan dan sekaligus masa kritis dalam tahapan kehidupan manusia. Karena itu, pada masa usia taman kanak-kanak merupakaan masa yang sangat tepat untuk menanamkan dan menumbuhkan nilai-nilai dasar yang bersumber dari pendidikan Islam guna memperkuat karakter anak didik. Sehingga upaya pengembangan seluruh potensi anak secara dini dapat dimulai, agar pertumbuhan dan perkembangan anak berdasarkan nilai-nilai ajaran Islam dapat memperkuat karakter.

Kesadaran masyarakat teresebut direalisasikan sehingga TK Mawaddah dengan cirikhas taman kanak-kanak Islam berdiri 15 November 1991 di bawah naungan Yayasan Taman Pendidikan Sakinah dengan Surat Izin Operasional Nomor: Kep.87/I.15. a 3/I. 1991 beralamat di Jalan Cempaka IV/ 35 Kel. Mawar Kec. Banjarmasin Tengah Kota Banjarmasin Kalimantan Selatan.

${ }^{22}$ Miles Mattew B \& A. Michael Huberman. 1984. Qualitative Data Analysis. New York: Sage Publication, Inc., h. $15-18$.

${ }^{23}$ Wawancara dengan Wakil Kepala TK Mawaddah Khairil Anwar dilakukan 6 Juni 2012. 
Kepengurusan Yayasan Taman Pendidikan Sakinah ${ }^{24}$ terdiri dari:

- Pelindung: Camat Kec. Banjarmasin Tengah dan Lurah Kel. Mawar.

- Penasehat: Dra. Hj. Kartini Fahmi Idris dan H. Arselan Tawab.

- Badan Pengurus:

- Ketua: Drs. H. M. Chairani Noor

- Wakil Ketua: Hj. Noor Aini As, BA

- Sekretaris: H. Ahsani Taqwiem, ST

- Bendahara: Hj. Aida Adhiyani

Memperhatikan personil kepengurusan yayasan di atas, dapat dipahami bahwa hal tersebut merupakan salah satu startegi untuk lebih meningkatkan mutu pendidikan dan sekaligus merupakan "dinamo pembangkit" animo masyarakat untuk memasukkan anakanaknya ke taman kanak-kanak ini. Karena umumnya personil tersebut, adalah tokohtokoh agama/masyarakat, misalnya terdapat nama besar dan penuh kharisma, terutama dalam masyarakat Islam yang mayoritas di Kota Banjarmasin, antara lain; Dra. Hj. Kartini Fahmi Idris, selain berpendidikan tinggi (sarjana) dan istri mantan Menteri Tenaga Kerja dan Transmigrasi, juga putri almarhum KH. Hasan Basri seorang ulama besar dan mantan Ketua Umum MUI memiliki kharisma yang masih berakar kuat di tengah-tengah masyarakat.

Yayasan Taman Pendidikan Sakinah, selain menyelenggarakan pendidikan formal, yaitu TK Mawaddah anak usia 4-6 tahun. Juga menyelenggarakan pendidikan nonformal, yaitu: Kelompok Bermain (Play Group) anak usia 2 - 3 tahun dan Taman Pengasuhan Anak (TPA) anak usia $2-6$ tahun. Namun, pengurus yayasan ini menjadikan TK Mawaddah sebagai "program unggulan" dengan visi-misi, sebagai berikut:

Visi "menjadikan seluruh komunitas Pendidikan Anak Usia Dini Mawaddah Banjarmasin

\footnotetext{
${ }^{24}$ Sumber: Dokumen TK Mawaddah Kota Banjarmasin, tahun 2012.
}

(anak didik, pendidik, pengelola, orangtua anak didik dan yayasaan) untuk tumbuh sesuai perannya masing-masing, berakar kuat secara lahir dan bathin serta membuahkan manfaat bagi masyarakat di sekitarnya, terutama di bidang pendidikan Islam".

Sedangkan Misinya adalah:

1. Mengembangkan potensi anak secara utuh dengan seluruh kecerdasan majemuk yang dibawa sejak lahir.

2. Melaksanakan program pembelajaran melalui bermain yang dinamis, inovatif dan kreatif dengan bidang pengembangan: nilai, moral (ajaran Islam), kognitif, bahasa, fisik motorik, kemandirian dan kemampuan bersosialisasi berdasarkan akhlaqul karimah.

3. Menginternalisasikan nilai-nilai pendidikan Islam kepada anak didik melalui pengenalan, pembiasaan dan keteladanan.

4. Mengembangkan program pembelajaran yang berpusat pada anak, sesuai dengan keunikan individu anak dan tahap perkembangannya.

5. Mengembangkan program pembelajaran melalui bermain yang menjadikan anak didik senang, serius dan nyaman belajar.

6. Mengembangkan program pembelajaran melalui bermain yang menjadikan seluruh komunitas PAUD Mawaddah Banjarmasin (anak didik, pendidik, pengelola dan orangtua anak didik) sebagai "pembelajar sepanjang hayat".

Untuk mencapai visi-misi di atas, Pengurus Yayasan Taman Pendidikan Sakinah berupaya untuk mengangkat pendidik dan tenaga kependidikan sesuai kebutuhan. Karena itu, tahun 2012 TK Mawaddah memiliki pendidik (guru) 18 orang dan tenaga kependidikan (tenaga administrasi) 3 orang. Dalam hal ini, menurut Peraturan Menteri Pendidikan Nasional RI Nomor 58 Tahun 2009 Tentang Standar Pendidikan Anak Usia Dini, disebutkan bahwa pendidik anak usia dini adalah 
profesional yang bertugas merencanakan, melaksanakan proses pembelajaran dan menilai hasil pembelajaran serta melakukan pembimbingan, pengasuhan dan perlindungan anak didik.

Oleh karena itu, jika pendidik anak usia dini TK Mawaddah dilihat dari jenis kelamin, sebagian besar, $16(88,89 \%)$ perempuan dan sebagian kecil, 2 (11,11\%) laki-laki. Jika ditelusuri lebih mendalam, dapat diketahui bahwa 2 orang laki-laki tersebut adalah Kepala dan Wakil Kepala TK Mawaddah. Hal ini tidak berarti, pengurus yayasan lebih cenderung mengangkat "pimpinan" dari kaum "lakilaki". Tapi, lebih didukung oleh alasan bahwa kepala dan wakil ini dipandang memenuhi kualifikasi akademik dan memiliki kompetensi dalam memimpin taman kanak-kanak ini, yaitu M. Dani Wahyudi, M. Pd sebagai kepala, beliau magister pendidikan dan dosen salah satu Fakultas di Unlam. Juga Khairil Anwar, S. Ag, S.Pd. I sebagai wakil, adalah sarjana pendidikan IAIN.

Apabila pendidik dilihat dari tingkat pendidikan, terbanyak $8(44,44 \%)$ orang D-II, sedangkan SLTA $6(33,33 \%)$ orang dan hanya sebagian kecil, 3 (16,67\%) orang sarjana dan $1(5,55 \%)$ orang magister. Berkaitan dengan Standar Pendidik, maka Kualifikasi Akademik dan Kompetensi Guru PAUD didasarkan atas Peraturan Menteri Pendidikan Nasional RI Nomor 16 Tahun 2007 Tentang Standar Kualifikasi Akademik dan Kompetrensi Guru. Sedangkan bagi guru PAUD jalur pendidikan formal (TK) yang belum memenuhi kualifikasi akademik dan kompetensi disebut guru pendamping dan pengasuh.

Adapun kualifikasi akademik dan kompetensi guru pendamping, adalah, pertama; Kualifikasi akademik: (1) memiliki ijazah D-II PGTK dari perguruan tinggi terakreditasi, atau (2) ijazah minimal SMA atau sederajat dan memiliki sertifikasi pelatihan/ pendidikan/kursus PAUD yang terakreditasi. Kedua; kompetensi, adalah kepribadian, profesional, pedagogik dan sosial. Sedangkan kualifikasi akademik dan kompetensi guru pengasuh, adalah memiliki kualifikasi akademik minimun SMA atau sederajat dan memiliki kompetensi kepribadian, profesional, sosial dan manajemen.

Jika pendidik (guru) dilihat dari keikutsertaan dalam pendidikan dan pelatihan (diklat) yang berkaitan tugas dan fungsinya sebagai pendidik di taman kanak-kanak, maka semua (100\%) pendidik pernah mengikuti diklat yang diselenggarakan Kementerian Pendidikan Nasional dan berhasil memperoleh "sertifikat" diklat. Bahkan, di antara pendidik tersebut sebagian besar telah berulang-ulang kali mengikuti diklat. Ini menunjukkan, bahwa pendidik di TK Mawaddah telah memenuhi kualifikasi akademik dan kompetensi baik kompetensi guru pendamping maupun guru pengasuh, sehingga mereka memiliki integritas yang kuat untuk lebih meningkatkan kinerjanya.

Di samping itu, jika pendidik dilihat dari pengalaman mengajar (masa kerja), juga terdapat sebagian besar, 13 (72,22\%) pendidik telah memiliki pengalaman mengajar 10 tahun lebih. Bahkan, di antara pendidik tersebut 7 $(38,89 \%)$ orang telah memiliki pengalaman mengajar lebih 15 tahun. Ini menunjukkan, bahwa keikutsertaan pendidik dalam diklat yang diperkuat dengan pengalaman mengajar merupakan potensi besar bagi pendidik untuk lebih meningkatkan profesionalismenya dalam melaksanakan proses pembelajaran, pembimbingan, pengasuhan dan perlindungan anak didik.

Keadaan pendidik di atas, menunjukkan bahwa umumnya pendidik telah memenuhi kualifikasi akademik, sehingga mampu dan terampil menjalankan berbagai peran pendidikan, baik peran sebagai fasilitator, mediator, informator, motivator, evaluator, inovator maupun dinamisator dalam proses belajar melalui bermain. Hal ini penting dan strategi bagi pendidik di taman kanak-kanak ini untuk memiliki berbagai peran tersebut. Mengingat pada satu sisi anak didik di taman kanak-kanak hakikatnya merupakan "peniru kelas berat", maka pada sisi lain pendidik harus 
mampu menjadi "suri tauladan hasanah". Menurut Erikson sebagaimana dikutip oleh Arlen F. Harder dalam Danim ada delapan tahap perkembangan manusia, antara lain fase bermain usia 3-5 tahun, hasil perkembangan ego pada fase ini adalah inisiatif vs rasa bersalah, kekuatan dasarnya adalah tujuan/ dorongan. Selama periode ini anak mengalami suatu keinginan untuk meniru orang dewasa di sekitarnya dan mengambil inisiatif dalam menciptakan situasi bermain. ${ }^{25}$

Sehubungan dengan itu, observasi terhadap pendidik dan tenaga kependidikan (tenaga administrasi) ketika menjalankan tugas-tugasnya yang diperkuat wawancara dengan Wakil Kepala TK Mawaddah, dapat disimpulkan bahwa umumnya pendidik dan tenaga kependidikan selain memenuhi kualifikasi akademik, juga memiliki kompetensi dengan indikator, antara lain: ${ }^{26}$

a. Kompetensi keperibadian; pendidik selalu bersikap dan berperilaku sesuai kebutuhan psikologis anak didik, nilai-nilai ajaran Islam, budaya dan keyakinan anak didik serta pendidik mampu menampilkan diri sebagai pribadi yang amanah, jujur, disiplin, sopan-santun dan berbagai akhlakul karimah lainnya yang menghiasi sikap dan perilakunya.

b. Kompetensi pedagogik; melakasanakan proses pembelajaran melalui bermain (tidak main-main), memotivasi anak didik untuk meningkatkan partisipasi akatif dalam berbagai proses pembelajaran, membimbingan sesuai tingkat kebutuhan anak, mengolah hasil penilaian.

c. Kompetensi profesional; pendidik memahami standar tingkat pencapaian perkembangan anak, memahami aspekaspek perkembangan, kognitif, afektif, psikomotorik, sosial-emosi dan nilai-nilai ajaran Islam, mengenal kunikan setiap

${ }^{25}$ Sudarman Danim dan Khairil. 2010. Psikologi Perkembangan (Dalam Persepektif Baru). Bandung: Alfebata, h. 72 .

${ }^{26}$ Observasi dan wawancara dengan Wakil Kepala TK Mawaddah dilakukan 5-7 Juni 2012. anak, menguasai pola asah, asih dan asuh sesuai dengan tingkat perkembangan usia anak.

d.Kompetensi sosial; pendidik dapat menyesuaikan diri dengan teman-teman sejawat, metaati peraturan, akomodatif terhadap anak didik, orangtua, teman sejawat dari berbagai latar belakang budaya dan sosial ekonomi, berkomunikasi secara empatik baik secara verbal maupun non verbal.

Selanjutnya Wakil Kepala TK Mawaddah menuturkan, bahwa kompetensi pendidik di taman kanak-kanak ini sangat mendukung penyelenggaraan pendidikan, terutama dalam mendukung penguatan karakter anak melalui pembiasaan dan internalisasi nilai-nilai pendidikan Islam.

Begitupun tenaga kependidikan (tenaga administrasi) yang berjumlah 3 orang, di antaranya $1(33,33 \%)$ orang berijazah sarjana dan $2(66,67 \%)$ orang beriajazah SMA. Ini berarti, bahwa seluruh tenaga kependidikan telah memenuhi kualifikasi akademik dan memiliki kompetensi dengan indikator, antara lain:

a. Kompetensi keperibadian; mereka berakhlak mulia, bersikap terbuka, tekun, ulet, jujur dan bertanggung jawab dalam menjalankan tugasnya.

b. Kompetensi profesional; mereka mampu dan terampil mengaplikasikan teknologi informasi dalam sistem administrasi, mendokomentsikan data, memberi pelayanan administrasi, menegelola keuangan dengan prinsip pengelolaan yang akuntabel, transparan dan efisien.

c. Kompetensi sosial; mereka senantiasa menjalin kerjasama dengan para pendidik, pengurus yayasan, memiliki kepekaan sosial, bersikap dan berperilaku ramahtamah dalam memberi pelayanan.

d. Kompetensi manajemen; mereka merencanakan program ketatausahaan baik 
mingguan, bulanan maupun tahunan, melaksanakan program kerja secara terencana dan terarsipkan dengan baik, serta membuat laporan kegiatan.

Adapun sarana pendidikan yang merupakan bagian tidak terpisahkan dari komponen pendidikan lainnya dalam menunjang tingkat efektifitas proses pembelajaran di TK Mawaddah adalah tersedianya sarana pendidikan secara layak (kondisinya) dan sesuai kebutuhan (ketercukupannya). Dalam hal ini, sarana pendidikan dapat dimaknai sebagai perlengkapan untuk mendukung penyelenggaraan proses pendidikan, pengasuhan dan perlindungan anak didik. Karena itu, pengadaan sarana pendidikan dapat disesuaikan dengan jumlah anak didik, kondisi sosial, budaya dan jenis layanan pendidikan.

Sesungguhnya sarana pendidikan sangat luas dan kompleks, tapi dalam pembahasan ini dibatasi pada beberapa aspek yang mendukung pelaksanaan dan keberhasilan proses pembelajaran melalui bermain. Melalui observasi terhadap sarana pendidikan yang diperkuat dengan wawancara dapat disimpulkan, ${ }^{27}$ bahwa sarana pendidikan di TK Mawaddah, antara lain:

a. Ruang belajar; pada dasarnya ruang ini merupakan tempat bermain, sebab anak didik belajar melalui bermain. Ruang ini memiliki perlengkapan furnitur yang sesuai dengan ukuran anak didik serta mudah disusun/menyesuaikan dengan kebutuhan ruang kelas. Selain itu, cat dinding, plafon dan lantai/karpet sangat bervariasi warnanya yang dilengkapi dengan sejumlah hiasan educatif-islami, sehingga ruang ini sesuai dengan tingkat perkembangan psikologi anak. Ruang ini aman, nyaman dan menyenangkan, sehingga anak selalu merasakan kegembiraan dalam belajar. Menurut Meier kegembiraan dalam belajar dapat membangkitkan minat, keterlibatan penuh,

${ }^{27}$ Observasi dan wawancara dengan Wakil Kepala TK Mawaddah dilakukan 7-8 Juni 2012. terciptanya makna, pemahaman dan nilai yang membahagiakan bagi diri si pembelajar. ${ }^{28}$ Seirama pendapat ini, De Potter \& Hernacki mengemukakan, bahwa suasana menyenangkan merupakan keharusan agar belajar dapat berjalan efektif. ${ }^{29}$ Juga ruang ini memenuhi kriteria kesehatan, misalnya; ventilasi memadai sehingga sirkulasi udara lancar disertai cahaya penerangan yang layak, menurut Hathaway dalam Yamin bahwa penerangan yang cukup mempunyai pengaruh fisik dan kinerja positif anak-anak. ${ }^{30}$

b. Ruang ibadah; ruang ini tampak suci, bersih dan udara sejuk, sehingga sangat mendukung kegiatan anak, baik praktek ibadah maupun pelaksanaan ibadah, seperti; shalat berjama'ah dan berbagai kegiatan ibadah lainnya.

c. Arena bermain; bermain merupakan kesatuan yang tidak terpisahkan dari dunia anak, sebab bermain dapat membantu anak untuk memantapkan kesatuan pengetahuan, berpikir, bersikap, berimajinasi dan berperilaku. Karena itu, penataan lingkungan/arena bermain yang kondusif merupakan faktor terpenting dan strategi untuk mencapai kesuksesan pendidikan anak. Arena bermain TK Mawaddah terdapat sejumlah alat permainan yang educatifislami dan terjamin faktor keamanan dan kenyamanannya serta sesuai dengan tingkat kebutuhan dan perkembangan anak, sehingga anak dapat bermain dengan gembira-ria, bersosialisasi dengan temantemannya, saling menghargai, tolongmenolong dan sebagainya nilai-nilai ajaran Islam (akhlakul karimah) dapat terinternalisasikan ketika anak-anak bermain. Menurut Crowl, Keminsky \&

${ }^{28}$ Dave Meier. 2002. The Accelerated Learning: Handbook. Bandung: Kaifa, h. 36.

${ }^{29}$ Bobbi De Potter \& Mike Hernacki. 1999. Quantum Learning: Membiasakan Belajar Nyaman dan Menyenangkan. Bandung: Kaifa, h. 36.

${ }^{30}$ Martinis Yamin dan Jamilah Sabri Sanan. 2010. Op. Cit., h. 293. 
Podell permainan merupakan komponen utama untuk mendukung pertumbuhan dan perkembangan sosial anak. ${ }^{31}$ Juga Porter \& Hernacki mengemukakan, bermain dapat mengembangkan sistem emosional-kognitif. ${ }^{32}$

d. Halaman; cukup luas dan tampak dengan hijau, rindang, sejuk dengan berbagai tanaman hias tertata asri, sehingga dapat mewujudkan kesegaran anak didik yang sedang belajar melalui bermain di halaman sekolah.

e. Simbol-simbol agama; terdapat sejumlah simbol-simbol agama Islam sesuai cirikhas taman kanak-kanak ini (bercirikhas Islam) baik di dalam ruang belajar maupun di luar, sehingga keadaan di taman kanak-kanak ini sangat semarak dengan simbol-simbol agama Islam baik berupa tulisan (kaligrafi), gambar-gambar (foto-foto) maupun berupa nyanyian bernafaskan islami yang didengunkan pada jam-jam tertentu.

Sarana pendidikan di atas, telah disesuaikan dengan kebutuhan tingkat pertumbuhan dan perkembangan anak didik, kondisi sosial, budaya dan jenis layanan pendidikan, pengasuhan dan perlindungan anak didik di taman kanak-kanak ini. Selain itu, sarana pendidikan tersebut, pada hakikatnya merupakan sarana bermain bagi anak didik dalam rangka penguatan karakter melalui penanaman nilai-nilai dasar moral, sosial, emosional-kognitif yang bersumber dari pendidikan Islam. Menurut Kepala TK Mawaddah ${ }^{33}$ sarana (fasilitas) pendidikan di taman kanak-kanak ini cukup memadai baik dari segi kelayakan (kondisi) maupun dari segi ketercukupan (kebutuhan), hal ini sangat

${ }^{31}$ Thomas K Crowl \& Sally Kaminsky, David M. Podell. 1997. Educational Psychology: Windoms on Teaching. London: Brown \& Benchmark, h. 220.

${ }^{32}$ Bobbi De Potter \& Mike Hernacki. 1999. Op. Cit., h. 33.

${ }^{33}$ Wawancara dengan Kepala TK Mawaddah dilakukan 28 Mei 2012 menunjang penyelenggaraan pendidikan di taman kanak-kanak ini.

\section{Metode Pembelajaran}

Berdasarkan observasi yang diperkuat wawancara dengan Wakil Kepala dan pendidik TK Mawaddah dapat disimpulkan, ${ }^{34}$ bahwa sejak tahun 2006 menggunakan metode pembelajaran Beyond Centers and Circle Times (BCCT) yang dikenal dengan metode sentra, yaitu suatu metode pembelajaran yang mengembangkan berbagai jenis permainan yang sesuai taraf pertumbuhan dan perkembangan anak usia dini. Metode ini digunakan dengan alasan dapat memenuhi kebutuhan anak didik melalui berbagai kegiatan di sentra-sentra (beyond centers) dan mendapat berbagai pijakan dari pendidik pada saat lingkaran sebelum dan sesudah main (circle times). Selain itu, melalui metode ini pendidik dapat merumuskan berbagai langkah dalam proses pembelajaran sejak dari awal sampai akhir kegiatan bermain, sehingga pendidik dapat mengobservasi dan menilai tingkat perkembangan anak didik tersebut.

Ketika anak mendapat pijakan sebelum dan sesudah bermain dalam setting duduk melingkar, pendidik dan anak duduk sejajar dan semua anak saling berhadapan. Hal ini dapat menumbuhkan rasa dihargai, dihormati, diperhatikan, empati dan simpati. Pada saat anak bermain di sentra-sentra, setiap sentra tersedia berbagai pilihan permainan yang semuanya ditata sesuai dengan perkembangan dan kebutuhan anak. Kegiatan ini memberi kesempatan kepada anak untuk memilih permainan sesuai minat, tahap perkembangan dan kebutuhannya, sebab setiap anak adalah individu yang unik dan berbeda satu sama lain.

Pembelajaran dengan pendekatan bermain, anak tidak merasa takut tertinggal pelajaran, sehingga tidak ada unsur pemaksaan terhadap anak untuk mengejar ketinggalannya. Dalam hal ini, anak benar-benar belajar secara individual di bawah bimbingan dan 2012.

${ }^{34}$ Observasi dan wawancara dilakukan $6-8$ Juni 
pengasuhan pendidik, ini tidaklah berarti mendidik anak menjadi "individualis dan egois". Tapi, mendidik anak sesuai kebutuhan dan kemampuan sesuai tahapan tumbuhkembang setiap anak, sehingga anak belajar dengan senang dan nyaman (tidak terpaksa). Karena itu, setiap sentra tersedia berbagai pilihan kegiatan bermain yang juga memiliki tingkat kesulitan berbeda, anak yang tahap perkembangannya cepat tidak akan merasa jenuh, bosan dan lelah kerena mudah/ringan, sedangkan anak yang tahap perkembangannya sedang/lambat, tidak akan frustasi karena terlalu sulit/berat.

Setiap karya anak dirayakan untuk memberikan penghargaan, ini dimaksudkan agar anak lebih bersemangat dalam pembelajaran berikutnya. Selain itu, pada akhir kegiatan anak secara bergantian diberi kesempatan untuk lebih mengembangkan kemampuannya dalam mengemukakan ide-idenya dengan cara menceritakankembaliapayangtelah dilakukan. Sedangkan teman-temannya mendengarkan dengan baik (anak dilatih untuk membiasakan mendengarkan pendapat temannya). Selanjutnya, anak diberi kesempatan untuk mengembangkan kemampuan "berani mengajukan pertanyaan". Hal ini merupakan "latihan pembiasaan" untuk menghormati ide-ide temannya dan mengajukan pertanyaan denga "sopan-santun" (berkata mulia).

\section{Pengelolaan Lingkungan dan Sentra Bermain}

Menurut Yamin dan Sanan lingkungan berperan sangat besar dalam pembentukan sikap, kepribadian dan perkembangan kemampuan anak secara optimal. Anak yang tidak mendapat lingkungan yang baik untuk merangsang pertumbuhan otak, misalnya anak jarang disentuh dengan kasih-sayang, jarang diajak bermain, berkomunikasi dan sebagainya, maka perkembangan otaknya akan lebih kecil 20 - 30 persen dari ukuran normal seusianya. ${ }^{35}$ Ini berarti, pengelolaan lingkungan sangat

\footnotetext{
${ }^{35}$ Martinis Yamin dan Jamilah Sabri Sanan. 2010. Op. Cit., h. 285.
}

menentukan keberhasilan proses pembelajaran pada taman kanak-kanak, sebab hakikatnya lingkungan (tempat bermain) sekaligus merupakan ruang pembelajaran. Karena itu, jika pengelolaan lingkungan ditata dengan baik (sesuai kebutuhan dan perkembangan anak), maka dapat mewujudkan suasana aman, nyaman dan sejuk dalam kegiatan belajar.

Bermain sebagai suatu fenomena yang paling alamiah dan luas serta memegang peranan penting dalam proses perkembangan anak didik. Menurut Aqil ada lima pengertian sehubungan dengan bermain, yaitu: (1) sesuatu yang menyenangkan dan memiliki nilai positif bagi anak, (2) tidak memiliki tujuan ekstrinsik, tapi motivasinya lebih bersifat intrinsik, (3) bersifat spontan dan sukarela, (4) melibatkan peranserta aktif anak. ${ }^{36}$

Pengelolaan lingkungan, di antaranya menggunakan sistem kegiatan pembelajaran melalui bermain dengan mengaktifkan sentrasentra yang tersedia:

\section{Sentra Bermain Peran}

Dalam sentra ini disediakan berbagai peralatan yang telah dikenal anak didik, misalnya; peralatan shalat, rumah tangga, pakaian berbagai profesi, atau peralatan yang sering dilihat anak didik dalam kehidupan sehari-hari.

Kegiatan sentra ini anak dapat mengembangkan kemampuan dan keterampilannya dalam memerankan dirinya sebagai apa saja yang anak tersebut inginkan (sesuai kemauan anak), misalnya; dalam shalat berjama'ah seorang anak berperan sebagai imam dan teman-temannya sebagai makmum, atau dalam jual-beli, anak anak sebagai penjual dan lainnya sebagai pembeli dan sebagainya. Ini bertujuan untuk menginternalisasikan nilainilai akhlakul karimah, khususnya berkaitan dengan memelihara kerjasama, bersosialisasi,

${ }^{36}$ Zainal Aqib. 2011. Pedoman Teknik Penyelenggaraan Pendidikan Anak Usia Dini. Bandung: Nuansa Aulia, h. 6566. 
berkomunikasi, saling menghormati dan membiasakan kejujuran.

Meskipun tersedia tempat khusus yang dijadikan sebagai sentra peran, tapi tidak menutup kemungkinan anak "menginginkan" bermain peran di sentra-sentra lainnya, dengan peralatan bermain peran yang lebih kecil. Misalnya, di sentra balok tersedia bereneka ragam boneka yang dapat dimainkan setelah anak menyusunnya. Juga di sentra alam dilengkapi boneka berupa kendaraan, rumah-rumahan, pohon-pohonan kecil yang bisa digunakan untuk bermain peran mikro. Demikian pula, di sentra alam tersedia perabot rumah tangga, seperti piring, gelas untuk dicuci, pakaian kecil, boneka untuk dimandikan serta playdough yang berfungsi tidak hanya memperkuat motorik halus anak, tapi juga memberikan kesempatan kepada anak untuk bermain peran.

Ketika anak didik bermain peran, saat inilah merupakan peluang terbaik bagi pendidik untuk menginternalisasikan nilainilai pendidikan Islam melalui pengenalan dan pembiasaan akhlakul karimah kepada anak didik.

\section{Sentra Balok}

Tempat anak belajar melalui bermain untuk lebih mengembangkan kemampuan daya pikir, jasmani, daya cipta, bahasa dan keterampilan membangun (menyusun) dengan berbagai jenis dan ukuran balok-balok kayu dan bahan atau alat permainan pembangunan terstruktur (lego, bombiq, puzzie, balok unit dan sebagainya).

Keterampilan motorikhalus dan koordinasi mata dan tangan serta daya pikir matematis, bangun ruang (visual-spasial) mendominasi tujuan perkembangan anak dalam bermain di sentra balok. Hal ini dimaksudkan untuk menanamkan dan membiasakan anak tentang nilai-nilai kesabaran, ketelitian, keuletan dan kreativitas yang tinggi.

\section{Sentra Bahan Alam}

Tempat anak untuk menuangkan berbagai ide guna mempersiapkan diri dalam membaca dan menulis, matematika, daya pikir, jasmani (motorik), bahasa dan kreativitas dengan menggunakan bahan-bahan alami baik kering maupun basah (melukis, menggambar, mewarnai, memeras, menjumput, menggunting, meremas, mencetak dan sebagainya).

Dalam sentra ini kegiatan motorik halus anak mendominasi tujuan disediakannya semua jenis permainan tersebut. Ketika anak mencoba permainan di sentra bahan alam, koordinasi mata, tangan dan kekuatan otototot pergelangan tangannya akan terlatih, pada saatnya anak sudah terbiasa memegang alat tulis untuk menulis pada jenjang sekolah selanjutnya, sehingga anak tersebut tidak akan mengeluh karena capek atau mudah lelah dan letih.

\section{Sentra Persiapan}

Tempat anak belajar melalui bermain untuk mengembangkan kemampuan dasar persiapan membaca, menulis, matematika dan kegiatan khusus lainnya. Selain itu, di sentra ini dikembangkan kemampuan kognitif, motorik halus, keaksaraan dan bahasa anak dengan menggunakan sarana penunjang, seperti; menggunting, menempel, meronce, menggambar, mewarnai dan sebagainya.

Dalam kegiatan bermain dengan menggunakan pendekatan belajar melalui bermain dengan metode sentra, maka pendidik terlebih dahulu membuat jadwal perputaran sentra berdasarkan jumlah kelompok yang ada, sehingga perputaran sentra dalam waktu seminggu tidak terjadi benturan antar kelompok. Hal ini dimaksudkan agar anak dapat mengikuti kegiatan bermain di seluruh sentra sesuai dengan jadwal yang telah ditetapkan.

Tugas pendidik dalam kegiatan sentra bermain adalah mengarahkan, mengatur kegiatan dan bertanggung jawab terhadap sentra masing-masing, sehingga pendidik 
mengetahui lebih jauh tentang tingkat perkembangan setiap anak dalam kelompok sentra tersebut. Dalam kegiatan sentra, anak harus bermain bersama dengan temantemannya minimal 2 orang anak. Hal ini bertujuan, agar anak memiliki teman bicara dalam mengembangkan bahasa, terutama membiasakan anak menggunakan bahasa dengan kata-kata yang mulia dan menghindari kata-kata yang tidak sopan.

Prinsip belajar melalui bermain tersebut, sejalan dengan pendapat Piaget tentang bagaimana anakbelajar, mengemukakan bahwa "bermain adalah dunia anak". Karena itu, anak seharusnya melakukan percobaan sendiri, sedangkan pendidik tentu saja bisa menuntun anak-anak dengan menyediakan bahan-bahan yang tepat untuk belajar melalui bermain. Tapi yang terpenting agar anak dapat memahami sesuatu, anak harus membangun pengertian itu sendiri dan anak harus menemukannya sendiri. ${ }^{37}$ Selain itu, menurut Pamela C. Phelps pakar pendidikan anak usia dini dalam Aqib menekankan bahwa permainan harus melatih sensor motorik anak secara wajar. Bersamaan dengan itu, diperkenalkan pendidikan budi pekerti demi pembentukan karakter. ${ }^{38}$

Berdasarkan observasi terhadap anak didik TK Mawaddah yang sedang belajar melalui bermain, ternyata anak-anak tersebut "tidak main-main", tapi bermain dengan serius (serius sesuai tingkat berkembangan anak taman kanak-kanak). Sedangkan pendidik selalu memperhatikan dan membimbingnya dengan penuh antusias, tanpa mengenal lelah dalam menanamkan dan membiasakan nilainilai karakter melalui pendidikan Islam . Dari wajah pendidik terpancar sinar kebahagiaan dan kepuasan yang penuh dengan keakraban menyaksikan anak didiknya yang berpakaian muslim/muslimah dalam proses belajar melalui bermain. Selain itu, pendidik dalam menuntun dan membimbing anak didiknya memiliki dedikasi yang tinggi (dedication to

${ }^{37}$ Jean Piaget. 1972. The Psychology of The Child. New York: Basic Books, h. 97-98.

${ }^{38}$ Zainal Aqib. 2011. Op. Cit., h. 7. excellence) percaya diri (confidence), kesabaran, rasa kasih-sayang, teguh dalam memberikan semangat kepada anak adiknya yang kelihatan agak lelah dan pendidik ini selalu berada di tengah-tengah anak didiknya. ${ }^{39}$

Selanjutnya, pendidik TK Mawaddah ini mengungkapkan, bahwa dalam menanamkan dan membiasakan nilai-nilai karakter anak didik melalui pendidikan Islam, maka aspek perkembangan anak didik yang selalu harus mendapat perhatian, adalah: nilai-nilai ajaran Islam, fisik motorik, kognitif, bahasa dan sosial emosional. Karena itu, dalam menggunakan metode sentra pendidik dituntut berada di tengah-tengah anak didiknya, sehingga berbagai aspek perkembangan anak didik dapat diketahui dengan baik. Meskipun, pendidik harus menyadari bahwa anak didik taman kanak-kanak tidak diatur pikiran dan pengetahuan mereka dalam bentuk mata pelajaran, seperti; membaca, matematika, ilmu alam dan berbagai mata lainnya. Tapi, pikiran anak didik diatur melalui kegiatan dengan kerangka pikiran sendiri.

\section{Strategi Penguatan Karakter}

\section{Peran Pendidik}

Kepala TK Mawaddah mengemukakan, ${ }^{40}$ bahwa Yayasan Pendidikan Sakinah telah mengangkat pendidik (guru) di taman kanakkanak ini dari perempuan dengan alasan bahwa perempuan memiliki sifat naluri yang kuat untuk mendidik. Naluri tersebut, antara lain; memiliki sifat yang lemah-lembut, penuh kesabaran, keuletan dan kasih sayang, serta selalu merasa akrab dengan anak didik, baik secara pisik maupun psikis.

Sifat-sifat tersebut sangat penting dimiliki pendidik di taman kanak-kanak, agar anak didik selalu merasakan "kehangatan" dengan pendidiknya, bagaikan ibu kandungnya sendiri dan sebaliknya pendidik bagaikan anak kandung sendiri. Karena itu, pendidik

\footnotetext{
${ }^{39}$ Observasi dilakukan $5-7$ Juni 2012.

${ }^{40}$ Wawancara dengan Kepala TK Mawaddah
} dilakukan 28 Mei 2012. 
di taman kanak-kanak ini, juga berperan sebagai "orangtua" dari anak didiknya dan bahkan berperan sebagai "sahabat atau teman" dalam bermain. Hal ini sangat penting bagi pendidik, sehingga anak didik merasa aman, nyaman, kreatif, dinamis dan bergairah dalam belajar melalui bermain. Jika kondisi ini terpatri dengan kuat antara anak didik dengan pendidik, maka jalan untuk mencapai visi-misi dan tujuan pendidikan di taman kanak-kanak ini dengan mudah akan terwujud.

Kondisi yang demikian, dapat mewujudkan suasana belajar yang penuh dengan kasihsayang, menerima anak didik sebagaimana adanya dan menghargai potensi yang dimilikinya, sehingga dengan mudah pendidik memberi rangsangan terhadap berbagai aspek perkembangan anak didik, baik secara kognitif, afektif, sosioemosional, etika, moral dan psikomotorik.

Di samping itu, menurut Kepala TK Mawaddah, pendidik di taman kanak-kanak ini tidak ada yang khusus ditunjuk sebagai guru "pendidikan agama". Tapi, semua pendidik berperan secara aktif untuk menyampaikan (menginternalisasikan) nilai-nilai karakter yang bersumber dari ajaran Islam kepada anak didik melalui metode sentra yang didukung oleh berbagai pendekatan dan strategi yang tepat. Hal ini dimaksudkan, agar penguatan karakter anak didik berlangsung selama dalam proses belajar melalui bermain, sehingga penanaman penguatan karakter tidak hanya terbatas pada pendidik tertentu saja dalam waktu terbatas. Tapi, semua pendidik berperan aktif menginternalisasikan nilai-nilai ajaran Islam sebagai upaya penguatan karakter anak didik melalui pendidikan Islam.

Peran aktif pendidik tersebut sangat penting dan strategi dalam penguatan karakter, mengingat bahwa pada prinsipnya kegiatan belajar melalui bermain harus ditujukan pada pemenuhan kebutuhan perkembangan anak didik secara individu. Hal ini disebabkan, karena anak didik merupakan individu yang unik dan setiap anak didik memiliki kebutuhan yang berbeda antara satu dengan lainnya.
Karena itu, kegiatan belajar melalui bermain merupakan pendekatan dengan mengelola kegiatan belajar anak didik dengan menerapkan metode, strategi, sarana dan media belajar yang tepat, sehingga dapat merangsang anak didik untuk berkreativitas dan berinovasi dalam melakukan eksplorasi, menemukan dan menggunakan bahan-bahan pembelajaran yang tersedia. Ini menunjukkan, bahwa pendidik harus berperan sebagai pendidik yang benar-benar telah memiliki kemauan dan kemampuan mendidik, memahami anak didik, bersedia menumbuhkan dan mengembangkan potensi yang dimiliki anak didik, penuh kasih sayang dan kehangatan serta bersedia bermain dengan anak didik.

Uraian di atas, menunjukan bahwa peran seorang pendidik di taman kanak-kanak ini "berat tapimulia", sehingga menuntut pendidik untuk selalu meningkatkan kualitasnya. Karena itu, menurut Wakil Kepala TK Mawaddah ${ }^{41}$ Yayasan Taman Pendidikan Sakinah dan Komite TK Mawaddah telah menetapkan kebijakan untuk memprogramkan peningkatan kualitas pendidik di taman kanak-kanak ini. Program peningkatan kualitas pendidik tersebut, terdiri dari: in house training, workshop, studi banding, magang dan pendidikan dan pelatihan. Program ini mendapat dukungan baik material maupun moral dari berbagai pihak, antara lain: Pemerintah Daerah, Dinas Pendidikan Nasional, tenda Mawaddah, Mawaddah catering, Mawaddah toys dan masyarakat.

Begitupun, Wakil Kepala TK Mawaddah menuturkan, bahwa sejak berdiri taman kanakkanak ini sampai sekarang pihak Kementerian Agama (Kantor Kementerian Agama Kota Banjarmasin) hanya sekali memberi bantuan, yaitu beberapa tahun yang lalu memberi bantuan berupa uang sebanyak satu juta lima ratus ribu rupiah. Pemberian bantuan tersebut, tanpa penjelasan digunakan untuk apa dan tindak lanjutnya bagaimana? Pada hal, menurut beliau sesungguhnya pihak

${ }^{41}$ Wawancara dengan Wakil Kepala TK Mawaddah dilakukan 6 Juni 2012. 
dari Kementerian Agama sangat diharapkan pembinaannya, terutama dalam bidang pendidikan Islam.

\section{Pengembangan Kurikulum}

Beradasarkan dokumen yang diperkuat obeservasi dan wawancara dengan pendidik TK Mawaddah, ${ }^{42}$ dapat disimpulkan bahwa pengembangan kurikulum di taman kanakkanak ini dilakukan dengan mengacu kepada Peraturan Menteri Pendidikan Nasional RI Nomor 58 Tahun 2009 Tentang Standar Pendidikan Anak Usia Dini. Pada prinsipnya, pengembangan kurikulum tidak dimasukkan sebagai mata pelajaran atau pokok bahasan, tapi melalui pendekatan tematik integratif sehingga satu tema dapat menjangkau berbagai aspek. Ini berarti, bahwa standar pendidikan anak usia dini merupakan bagian integral dari Peraturan Pemerintah RI Nomor 19 Tahun 2005 Tentang Standar Nasional Pendidikan yang dirumuskan dengan tetap mempertimbangkan berbagai karakteristik penyelenggaraan pendidikan anak usia dini.

Oleh karena itu, Standar Pendidikan Anak Usia Dini yang terdiri dari: standar tingkat pencapaian perkembangan, standar pendidik dan tenaga kependidikan, standar isi, proses dan penilaian serta standar sarana-prasarana, pengelolaan dan pembiayaan saling terkait antara satu dengan lainnya harus menunjang pengembangan kurikulum dan proses belajar melalui bermain. Hal ini dapat mewujudkan suasana pembelajaran lebih dinamis dan pada akhirnya dapat merangsang anak didik untuk menumbuhkan dan mengasah kreativitasnya, sehingga dapat memberikan pelayanan pendidikan berkualitas yang bermuara kepada penguatan karakter anak didik melalui pendidikan Islam dengan pendekatan tematik integratif sesuai tingkat kebutuhan pertumbuhan dan perkembangan anak didik.

Dengan demikian, kurikulum yang diterapkan di taman kanak-kanak ini, pendidik sama sekali tidak mendikte, indoktrinatif dan

\footnotetext{
${ }^{42}$ Sumber: Dokumen TK Mawaddah 2012. Observasi dan wawancara dilakukan 5-7 Juni 2012.
}

memaksakan kehendak, sebab anak didik belajar melalui bermain bukanlah seperangkat materi pembelajaran yang harus dihafalkan oleh anak didik. Tapi, pendidik memberikan stimulus, pembinaan, pembiasaan dan pengasuhan secara konsisten agar anak didik memiliki kemampuan mengenal dan menerima nilai-nilai ajaran Islam sebagai miliknya dalam penguatan karakter. Karena itu, penguatan karakter anak didik dilakukan melalui setiap proses pembelajaran yang juga didukung oleh berbagai kegiatan ekstrakurikuler. Dalam hal ini, menurut Kepala TK Mawaddah ${ }^{43}$ kebijakan penguatan pendidikan agama Islam juga dilakukan melalui kegiatan ekstrakurikuler, meliputi: kegiatan shalat berjama'ah, membaca iqra, do'a-do'a harian, ramadhan ceria, dan jum'at taqwa diisi dengan kegiatan: membaca/ menghafal surat-surat pendek, cerita sejarah Islam, cerita para nabi dan rasul. Sedangkan ekstrakurikuler dalam bidang keseinian, meliputi: drum band, seni tari dan seni lukis yang bernafaskan ajaran Islam.

\section{Pembiasaan dan Keteladanan}

Berdasarkan Kepmendikbud Nomor 0486/U/1992 Pasal 3 ayat (1) tujuan penyelenggaraan TK adalah membantu meletakkan dasar ke arah perkembangan sikap, perilaku, pengetahuan dan keterampilan dan daya cipta anak didik untuk pertumbuhan dan perkembangan selanjutnya. Untuk meletakkan dasar-dasar perkembangan tersebut, khususnya berkaitan dengan sikap dan perilaku menurut pendidik TK Mawaddah ${ }^{44}$ adalah melalui pembiasaan dan keteladanan hasanah sejak anak usia dini, ini sesuai dengan kata-kata hikmah "ta'limu fishshighari kannaksi alal hajari wata'limu filkibari kannaksi alal ma'i" (belajar waktu kecil bagaikan mengukir di atas batu dan belajar waktu besar (dewasa) bagaikan mengukir di atas air". Hal ini senada dengan Aamodt \& Wang yang mengemukakan, bahwa lebih mudah untuk membentuk otak pada anak

\footnotetext{
${ }^{43}$ Wawancara dilakukan 28 Mei 2012.

${ }^{44}$ Wawancara dilakukan 5 - 7 Juni 2012.
} 
usia dini dari pada anak usia setelahnya. ${ }^{45}$ Ini berarti, bahwa internalisasi pendidikan Islam melalui pembiasaan dan keteladanan yang diberikan kepada anak usia dini (taman kanakkanak) dapat membekas selama-lamanya dan akhirnya dapat membentuk dan memperkuat karakter anak. Tapi, jika anak sudah dewasa baru diberikan pembiasaan dan keteladanan, mereka sulit meniru apalagi menerimanya. Menurut Montessori dalam Dewantara tak ada satu apapun yang berhasil terbentuk pada masa kanak-kanak dapat dihapus sepenuhnya. ${ }^{46}$

Oleh karena itu, anak usia taman kanakkanak merupakan golden age yang sangat strategis dalam menanamkan pembiasaan, sebab pada saat ini merupakan usia kritis sekaligus strategis dalam proses pendidikan. Untuk itu, pada anak usia taman kanak-kanak ini sikap dan perilaku hasanah sangat penting untuk diinternalisasikan melalui pembiasaaan dan keteladanan, seperti; nilai-nilai kejujuran, hemat, tolong-menolong, hormatmenghormati dan berbagai nilai-nilai akhlakul karimah lainnya. Pembiasaan bersikap dan berperilaku hasanah ini, ditanamkan kepada anak didik melalui proses belajar-bermain, sehingga dapat memperkuat karakter anak didik, akhirnya kelak anak tersebut "merasa bersalah" jika tidak bersikap dan berperilaku hasanah dalam kehidupan sehari-harinya.

Di samping itu, menurut pendidik TK Mawaddah, bahwa anak usia dini memiliki kecenderungan yang kuat untuk meniru dan mengikuti perilaku yang tumbuh dan berkembang di sekitarnya. Bahkan, semua perilaku yang dilakukan oleh orang dewasa, khususnya orangtua dan guru baik perilaku terpuji maupun buruk anak akan meniru dan mengikutinya. Karena itu, orangtua dalam keluarga dan guru di taman kanak-kanak ini adalah pihak yang paling dekat dengan anak, sehingga segala sikap dan perilaku yang terjadi dalam keluarga dan taman kanak-kanak ini akan menjadi teladan bagi anak. Untuk itulah,

${ }^{45}$ Sandra Aamodt \& Sam Wang. 2008. Welcome To Your Brain. New York: Bloomsbury, h. 71.

${ }^{46} \mathrm{Ki}$ Hadjar Dewantara. tt. Op. Cit., h. 242. orangtua dan pendidik harus bersenerji dalam bersikap dan perilaku hasanah agar menjadi teladan yang subur bagi anak. Menurut Vaugham \& Hogg seseorang, terutama kanakkanak dapat bertingkah laku berdasarkan kepada model yang ia lihat. ${ }^{47}$

Sehubungan dengan itu, Wakil Kepala TK Mawaddah mengungkapkan, ${ }^{48}$ bahwa untuk membekali orang tua, khususnyaibuanak didik, maka taman kanak-kanak ini memprogramkan "Parenting Class", kegiatannya adalah mengajak para ibu-ibu anak didik ke TK Mawaddah untuk membahas dengan para ahli pendidikan tentang bagaimana strategi yang tepat menginternalisasikan nilai-nilai ajaran Islam melalui pembiasaan dan keteladanan hasanah kepada anak dalam keluarga. Parenting class ini sangat penting dan strategis, mengingat pendidik pertama dan utama adalah orangtua dalam keluarga, sehingga interaksi anak dengan orangtua dan anggota keluarga lainnya turut menentukan tumbuh kembang anak. Karena pengalaman yang dirasakan, dilihat, didengar dan dialami anak dalam keluarga memberikan warna karakter anak. Ini berarti, penguatan karakter membutuhkan metode, pendekatan dan strategi yang tidak tunggal, tapi di dalamnya pembiasaan, keteladanan dan interaksi sosial sebagai strategi utama.

Parenting class ini dimaksudkan untuk memperluas dan memperdalam wawasan dan kemampuan orangtua dalam mendidik anakanaknya, khususnya dalam menanamkan pembiasaan dan keteladanan hasanah kepada anaknya selama di rumah, sehingga pendidikan yang telah diinternalisasikan kepada anak didik secara konsisten dapat berlanjut dan bersenerji dengan pendidikan dalam keluarga, sebab kedua pendidik ini (orangtua dan guru) sangat potensial untuk menginternalisasikan nilai-nilai pendidikan Islam, sebab mereka inilah memiliki keakraban, kehangatan dan kesempatan relatif panjang dalam bergaul dengan anak, sebab anak sangat intens dalam

${ }^{47}$ Graham Vaugham \& Michel Hogg. 1995. Introduction to Social Psychology. New York: Prentice Hall, h. 2006.

${ }^{48}$ Wawancara dilakukan 6 Juni 2012. 
meniru dan meneladani berbagai sikap dan perilaku baik dari orangtua maupun gurunya. Sehingga pada gilirannya nilai-nilai pendidikan Islam dapat berakar, tumbuh dan berkembang dengan subur menghiasi sikap dan berilaku anak dan akhirnya menjadi pondasi yang kokoh untuk memperkuat karakter anak ketika usia dewasa kelak.

\section{PENUTUP}

\section{Kesimpulan}

1. Sejak berdiri TK Mawaddah telah konsisten menginternalisasikan nilai-nilai pendidikan Islam dengan kesadaran dan keyakinan bahwa nilai-nilai tersebut dapat menjadi pondasi yang kokoh dalam penguatan karakter anak didik. Hal ini dapat diketahui dari ketersediaan, ketercukupan dan kelayakan komponenkomponen pendidikan yang umumnya telah memenuhi standar pendidikan anak usia dini.

2. Sejak 2006 pendidik TK Mawaddah dalam proses pembelajaran menggunakan metode Beyond Centers and Circle Tim. Metode ini sangat relevan dengan kebutuhan anak, yaitu dunia bermain tapi "bukan main-main". Karena itu, metode ini sangat mendukung penguatan karakter anak didik melalui internalisasi nilai-nilai pendidikan Islam.

3. Strategi penguatan karakter anak didik didukung oleh penggabungan berbagai ide, pengalaman dan saling percaya para pendidik yang berdedikasi. Selain itu, strategi penguatan karakter melalui internalisasi pendidikan Islam tidak hanya terbatas di taman kanak-kanak ini. Tapi bersenerji dengan pendidikan dalam keluarga yang didukung oleh kemampuan dan keterampilan orangtua untuk mendidik anak yang diperoleh melalui kegiatan parenting class.

4. Penguatan karakter anak didik tidak bisa ditumbuh-kembangkan secara instan dan liner. Tapi, harus melalui proses panjang, berkesinambungan dan berkelanjutan (never ending proses) dengan menginternalisasikan nilai-nilai pendidikan Islam dalam proses pembelajaran melalui pengenalan, pembiasaan dan keteladanan hasanah baik oleh pendidik maupun orangtua. Untuk itu, penguatan karakter anak didik mustahil bisa dilakukan dengan efektif hanya dengan cara diajarkan berupa mata pelajaran, sebab pada prinsipnya karakter bukan mata pelajaran.

\section{Rekomendasi}

1. Sebaiknya Direktorat Pembinaan Anak Usia Dini Dinas Pendidikan Kota Banjarmasin sebelum memberikan bantuan (sarana/ fasilitas) pendidikan kepada taman kanakkanak, terlebih dahulu mensurvei taman kanak-kanak mana saja yang benarbenar (prioritas) membutuhkan bantuan, sehingga bantuan tersebut tepat sasaran. Juga dari hasil survei tersebut diharapkan memperoleh data yang akurat tentang kebutuhan sarana/fasilitas pendidikan apa dan bagaimana yang benar-benar dibutuhkan, akhirnya bantuan tersebut dapat bermanfaat dengan lebih efektif dan efisien.

2. Sebaiknya Direktorat Pembinaan Anak Usia Dini Dinas Pendidikan Kota Banjarmasin mempertimbangkan dan menetapkan TK Mawaddah sebagai salah satu model penguatan karakter anak didik melalui pendidikan Islam, khususnya berkaitan komponen-komponen sistem pendidikannya, metode pembelajarannya dan strategi penguatan karakter anak didik.

3. Peningkatan kualitas pendidikan agama (Islam) merupakan tanggung jawab Kementerian Agama. Namun, selama ini pihak Kementerian Agama belum maksimal melakukan pembinaan pendidikan agama di taman kanak-kanak. Untuk itu, sangat diharapkan kepada Kanwil Kementerian 
Agama Provinsi Kalimantan Selatan lebih meningkatkan pembinaannya terhadap pendidikan agama di TK Mawaddah khususnya dan di taman kanak-kanak umumnya.

4. Diharapkan kepada Pengurus Yayasan Taman Pendidikan Sakinah, Kepala dan Wakil Kepala TK Mawaddah, para pendidik dan tenaga kependidikan beserta tokohtokoh agama/masyarakat senantiasa bersenerji untuk lebih meningkatkan pengelolaan dan penyelenggaraan pendidikan Islam sebagai cirikhas pendidikan di taman kanak-kanak ini.

\section{SUMBER BACAAN}

Aqib, Zainal (2011): Pedoman Teknik Penyelenggaraan Pendidikan Anak Usia Dini. Bandung: Nuansa Aulia.

Arifin, Muzayin (1981): Kapita Selekta Pendidikan (Umum \& Agama). Semarang: Toha Putra.

Bogdan, Robert C. \& S. Knopp Biklen (1992): Qualitative Research for Education: an Intruduction to Theory and Methods. Boston: Allyn and Bacon, Inc.

Chaedar, A. Alwasilah (2003): Pokoknya Kualitatif. Jakarta: Dunia Pustaka Jaya.

Crowl, Thomas K, \& Sally Kaminsky, David M. Podell (1997): Educational Psychology: Windoms on Teaching. London: Brown \& Benchmark

Danim, Sudarman dan Khairil (2010): Psikologi Perkembangan (Dalam Persepektif Baru). Bandung: Alfebata.

De Potter, Bobbi \& Mike Hernacki (1999): Quantum Learning: Membiasakan Belajar Nyaman dan Menyenangkan. Bandung: Kaifa.

Dewantara, Ki Hadjar (tt): Karya Ki Hadjar Dewantara Bagian Pertama Pendidikan. Yogyakarta: Mejelis Luhur Persatuan Taman Siawa.

Glaser, Barney \& Anselm L. Strauss (1980): The Discovery of Grounded Theory. New York: Aldine Publishing Company.
Kutha, Nyoman Ratna (2010): Metodologi Penelitian.Yogyakarta: Pustaka Pelajar

Langgulung, Hasan (1987): Asas-Asas Pendidikan Islam. Jakarta: Pustaka Al Husna.

Miles, Mattehew B. \& A. Michael Huberman (1984): Qualitative Data Analysis. New York: Sage Publication, Inc.

Muhammad, AR. (2003): Pendidikan di Alaf Baru: Rekonstruksi Atas Moralitas Pendidikan. Yogyakarta: Prismashophie Press.

Muhaimin, et. al. (2002): Paradigma Pendidikan Islam. Bandung: Remaja Rosdakarya.

Meier, Dave (2002): The Accelerated Learning: Handbook. Bandung: Kaifa.

Moleong, Lexy J. (2004): Metodologi Penelitian Kualitatif. Bandung: Remaja Rosdakarya.

Piaget, Jean (1972): The Psychology of The Child. New York: Basic Books.

Pranowo, Bambang (2009): Mereka Berbicara Pendidikan Islam Sebuah Bunga Rampai (Masa Depan Pendidikan Islam), Jakarta: Rajagrafindo Persada.

Quinn Patton, Michael (1987): Qualitative Evaluation Methods. Beverly Hills: Sage Publication.

Rachman, Abd. Shaleh (2009): Mereka Berbicara Pendidikan Islam Sebuah Bunga Rampai (Peduli Masalah Pendidikan Islam: Revitalisasi dan Prospek Pendidikan Islam Bagi Perkembangan Anak Bangsa). Jakarta: Rajagrafindo Persada.

Soedarsono, Soemarno (2009): Karakter Mengantar Bangsa Dari Gelap Menuju Terang. Jakarta: Elex Media Kompurindo.

Wibowo, Agus (2012): Pendidikan Karakter: Strategi Membangun Karakter Bangsa Berperadaban. Yogyakarta: Pustaka Pelajar.

Yamin, Martinis dan Jamilah Sabri Sanan (2010): Panduan Pendidikan Anak Usia Dini. Jakarta: Gaung Persada Press.

Vaugham, Graham \& Michel Hogg (1995): Introduction to Social Psychology. New York: Prentice Hall. 